Supplement of Biogeosciences, 17, 3631-3642, 2020

https://doi.org/10.5194/bg-17-3631-2020-supplement

(C) Author(s) 2020. This work is distributed under

the Creative Commons Attribution 4.0 License.

(c) (1)

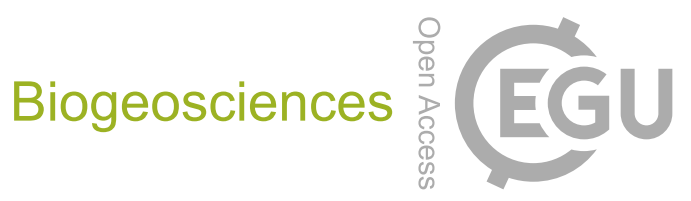

Supplement of

\title{
Contrasting decadal trends of subsurface excess nitrate in the western and eastern North Atlantic Ocean
}

Jin-Yu Terence Yang et al.

Correspondence to: Kitack Lee (ktl@ postech.ac.kr)

The copyright of individual parts of the supplement might differ from the CC BY 4.0 License. 


\section{Text S1}

Our analysis of NAtl nutrient data was primarily focused on data obtained during the past 3 decades. Previous studies have also confirmed that during this period the physical (i.e., potential temperature and salinity) and chemical (i.e., nutrients and oxygen) properties of deep waters (> $2000 \mathrm{~m}$ depth) in the western and eastern subtropical NAtl have not changed discernibly (Zhang et al., 2000; Gebbie and Huybers, 2012; Key et al., 2015; Olsen et al., 2016; Woosley et al., 2016). Moreover, we found no significant changes in salinity, potential temperature, and concentration of dissolved oxygen (DO) in the deep waters at the Bermuda Atlantic Time-series Study (BATS at 2000-3500 m depth) site in the western NAtl and at the Iceland Sea Time-series site $\left(68.0^{\circ} \mathrm{N}, 12.7^{\circ} \mathrm{W}\right.$; at $1500-1800 \mathrm{~m}$ depth $)$ in the eastern NAtl during the period 1990-2015 (Fig. S2).

The methods of nutrient and oxygen measurement in oceanography have been improved over time. The GO-SHIP program is an ongoing international repeat hydrography program and has provided the accurate oceanographic measurements using the most updated methodology (Talley et al., 2016). On each of the four transects the concentration profiles of nutrients and DO measured during the most recent cruises (the GO-SHIP program; Table S1) were used as the reference to correct the inaccuracy in historical data because of limitations in analytical technique and instrumentation used in early days. The differences (individual cruise data minus the GO-SHIP data) in concentrations of DIN, DIP, and DO in deep waters

53 (where the concentration gradients were smallest) within a pixel of $1^{\circ}$ (or $1.5^{\circ}$ ) latitude by $1.5^{\circ}$ longitude were then calculated (Fig. S1b). For each pixel the estimated differences for all parameters along the density layers were finally applied to all cruise data other than the reference GO-SHIP data collected from the same pixel (Fig. S3). This data adjustment method would minimize systematic errors in data used in our analysis (Zhang et al., 2000). 
59 (equivalent to changes in apparent oxygen utilization; AOU) were corrected using the

60 DIP:DIN:O 2 remineralization ratio of 1:15:(-160) (Anderson and Sarmiento, 1994). We

61 found no discernable effect of remineralization on any of the NAtl deep water DIN $_{\mathrm{xs}}$ values,

62 which is consistent with the results of previous studies (Broecker and Takahashi, 1980). For

63 individual locations, multiplicative adjustment factors for nutrient concentrations were

64 applied to the entire water column data if any differences were found in the deep waters (Key

65 et al., 2015; Olsen et al., 2016). 
66 Table S1. Detailed information of cruises and transects used in this study. Data collected in

67 these cruises were shown in Figure 1.

\begin{tabular}{|c|c|c|c|c|}
\hline $\begin{array}{c}\text { Program/ } \\
\text { Data source }\end{array}$ & Expocode & Date & Extent & $\begin{array}{l}\text { Nominal } \\
\text { Lat./Long. }\end{array}$ \\
\hline \multicolumn{5}{|c|}{$A 22$} \\
\hline GEOSECS & GEOSECS_ATL & $3 / 30 / 1973$ & $35^{\circ} \mathrm{N}-36^{\circ} \mathrm{N}$ & $67^{\circ} \mathrm{W}-68^{\circ} \mathrm{W}$ \\
\hline TTO & 316N19810401 & $4 / 5-4 / 25 / 1981$ & $18.5^{\circ} \mathrm{N}-36^{\circ} \mathrm{N}$ & $66^{\circ} \mathrm{W}$ \\
\hline WOCE & 316 N19970815 & $8 / 15-9 / 3 / 1997$ & $18.5^{\circ} \mathrm{N}-36^{\circ} \mathrm{N}$ & $66^{\circ} \mathrm{W}$ \\
\hline CLIVAR & 316 N20031023 & $10 / 23-11 / 13 / 2003$ & $18.5^{\circ} \mathrm{N}-36^{\circ} \mathrm{N}$ & $66^{\circ} \mathrm{W}$ \\
\hline GO-SHIP & 33AT20120324 & $3 / 24-4 / 17 / 2012$ & $18.5^{\circ} \mathrm{N}-36^{\circ} \mathrm{N}$ & $66^{\circ} \mathrm{W}$ \\
\hline \multicolumn{5}{|c|}{$A 20$} \\
\hline GEOSECS & GEOSECS_ATL & $9 / 20-9 / 28 / 1972$ & $18^{\circ} \mathrm{N}-34^{\circ} \mathrm{N}$ & $50^{\circ} \mathrm{W}-54^{\circ} \mathrm{W}$ \\
\hline NODC & $32 \mathrm{OC} 19830501$ & $5 / 1-5 / 17 / 1983$ & $15^{\circ} \mathrm{N}-36^{\circ} \mathrm{N}$ & $52^{\circ} \mathrm{W}$ \\
\hline WOCE & 316N19970717 & 7/17-8/10/1997 & $15^{\circ} \mathrm{N}-36^{\circ} \mathrm{N}$ & $52^{\circ} \mathrm{W}$ \\
\hline CLIVAR & 316 N20030922 & $9 / 22-10 / 23 / 2003$ & $15^{\circ} \mathrm{N}-36^{\circ} \mathrm{N}$ & $52^{\circ} \mathrm{W}$ \\
\hline GO-SHIP & 33АТ20120419 & $4 / 19-5 / 1 / 2012$ & $15^{\circ} \mathrm{N}-36^{\circ} \mathrm{N}$ & $52^{\circ} \mathrm{W}$ \\
\hline \multicolumn{5}{|c|}{$A 16 N$} \\
\hline WOCE & $32 \mathrm{OC} 19880723$ & $7 / 23-8 / 27 / 1988$ & $20^{\circ} \mathrm{N}-64^{\circ} \mathrm{N}$ & $20^{\circ} \mathrm{W}-25^{\circ} \mathrm{W}$ \\
\hline CLIVAR & 33RO20030604 & $6 / 4-8 / 1 / 2003$ & $20^{\circ} \mathrm{N}-64^{\circ} \mathrm{N}$ & $20^{\circ} \mathrm{W}-25^{\circ} \mathrm{W}$ \\
\hline GO-SHIP & 33RO20130803 & $8 / 13-9 / 9 / 2013$ & $20^{\circ} \mathrm{N}-64^{\circ} \mathrm{N}$ & $20^{\circ} \mathrm{W}-25^{\circ} \mathrm{W}$ \\
\hline \multicolumn{5}{|c|}{$A 05$} \\
\hline WOCE & 33RO19980123 & $1 / 23-2 / 24 / 1998$ & $75^{\circ} \mathrm{W}-14^{\circ} \mathrm{W}$ & $24.5^{\circ} \mathrm{N}$ \\
\hline CLIVAR & 74DI20040404 & $4 / 4-5 / 10 / 2004$ & $75^{\circ} \mathrm{W}-14^{\circ} \mathrm{W}$ & $24.5^{\circ} \mathrm{N}$ \\
\hline GO-SHIP & 74DI20100106 & $1 / 6-2 / 18 / 2010$ & $75^{\circ} \mathrm{W}-14^{\circ} \mathrm{W}$ & $24.5^{\circ} \mathrm{N}$ \\
\hline
\end{tabular}

68 
69 Table S2. Overall average adjustment factors (\%) obtained from comparisons of the nutrients

70 (DIN and DIP) concentrations for the deep water along the four transects at crossover

71 stations. The comparison data were taken from the depths with minimum concentration

72 gradients. The latest GO-SHIP cruises (see Table S1) were used as the reference against

73 which historical cruises were compared. The average adjustment factors for the DIN and DIP

74 are consistent to those in the GLODAPv2 product (Olsen et al., 2016).

\begin{tabular}{|c|c|c|}
\hline \multirow{2}{*}{$\begin{array}{c}\text { Transect/ } \\
\text { Cruise year }\end{array}$} & \multicolumn{2}{|c|}{ Average adjustment factor (\%) } \\
\hline & $\overline{\mathrm{DIN}}$ & DIP \\
\hline \multicolumn{3}{|l|}{$A 22$} \\
\hline 1997 & $0.75 \pm 0.57$ & $0.21 \pm 0.46$ \\
\hline 2003 & $-0.47 \pm 0.90$ & $-1.54 \pm 0.60$ \\
\hline \multicolumn{3}{|l|}{$A 20$} \\
\hline 1983 & $-0.39 \pm 1.01$ & $-0.71 \pm 1.48$ \\
\hline 1997 & $-0.07 \pm 0.63$ & $-0.44 \pm 0.57$ \\
\hline 2003 & $-0.17 \pm 0.76$ & $-0.78 \pm 0.76$ \\
\hline \multicolumn{3}{|l|}{$A 16 N$} \\
\hline 1988 & $0.50 \pm 1.56$ & $-4.03 \pm 3.00$ \\
\hline 2003 & $-0.02 \pm 1.60$ & $-1.31 \pm 1.99$ \\
\hline \multicolumn{3}{|l|}{$A 05$} \\
\hline 1998 & $0.14 \pm 1.68$ & $1.05 \pm 1.79$ \\
\hline 2004 & $0.63 \pm 3.41$ & $0.02 \pm 3.29$ \\
\hline
\end{tabular}

75 
76 Table S3. Locations of monitoring sites of atmospheric wet nitrogen deposition along the US

77 Atlantic coast. Annual average data of total inorganic nitrogen deposition were derived from

78 the sites with an observation period were greater than 15 years. Data are available at

79 http://nadp.sws.uiuc.edu/.

\begin{tabular}{cccc}
\hline Site ID & Latitude $\left({ }^{\circ} \mathrm{N}\right)$ & Longitude $\left({ }^{\circ} \mathrm{W}\right)$ & Observational Period \\
\hline FL03 & 29.9748 & 82.1978 & $1978-2016$ \\
FL05 & 28.7486 & 82.5551 & $1996-2016$ \\
FL11 & 25.3900 & 80.6800 & $1980-2016$ \\
FL41 & 27.3801 & 82.2831 & $1983-2016$ \\
FL99 & 28.5428 & 80.6440 & $1983-2015$ \\
GA09 & 30.7404 & 82.1283 & $1997-2016$ \\
GA20 & 32.0849 & 81.9367 & $1983-2016$ \\
MA01 & 41.9759 & 70.0241 & $1981-2016$ \\
ME96 & 43.8325 & 70.0645 & $1998-2016$ \\
ME98 & 44.3772 & 68.2608 & $1981-2016$ \\
NC03 & 36.1325 & 77.1708 & $1978-2016$ \\
NJ00 & 39.4728 & 74.4369 & $1998-2016$ \\
PR20 & 18.3206 & 65.8200 & $1985-2016$ \\
\hline
\end{tabular}

80 
a)

The original datasets from different cruises along each transect the GLODAPv2 and CLIVAR products

Systematic offsets:

Comparison of physical and chemical properties in deep waters along density layer (grey shadow in b) within a pixel of $1^{\circ} \times 1.5^{\circ}$

$\mathrm{D}_{\mathrm{AOU}}=\mathrm{AOU}_{\mathrm{i}}-\mathrm{AOU}_{\mathrm{r}}$

$\mathrm{AF}_{\mathrm{DIN}}=\left(\mathrm{DIN}_{\mathrm{i}}-\mathrm{DIN}_{\mathrm{r}}-\mathrm{D}_{\mathrm{AOU}} / 160 \times 15\right) / \mathrm{DIN}$

$\mathrm{AF}_{\mathrm{DIP}}=\left(\mathrm{DIP}_{\mathrm{i}}-\mathrm{DIP}_{\mathrm{r}}-\mathrm{D}_{\mathrm{AOU}} / 160\right) / \mathrm{DIP}_{\mathrm{r}}$

D: difference; AF: adjustment factor

$\mathrm{i}$ : cruise other than the reference ; r: reference cruise
Estimates of $\mathrm{DIN}_{\mathrm{xs}}(=\mathrm{DIN}-$

$15 \times$ DIP) in subsurface waters

AFs and errors shown in Table S2

b)

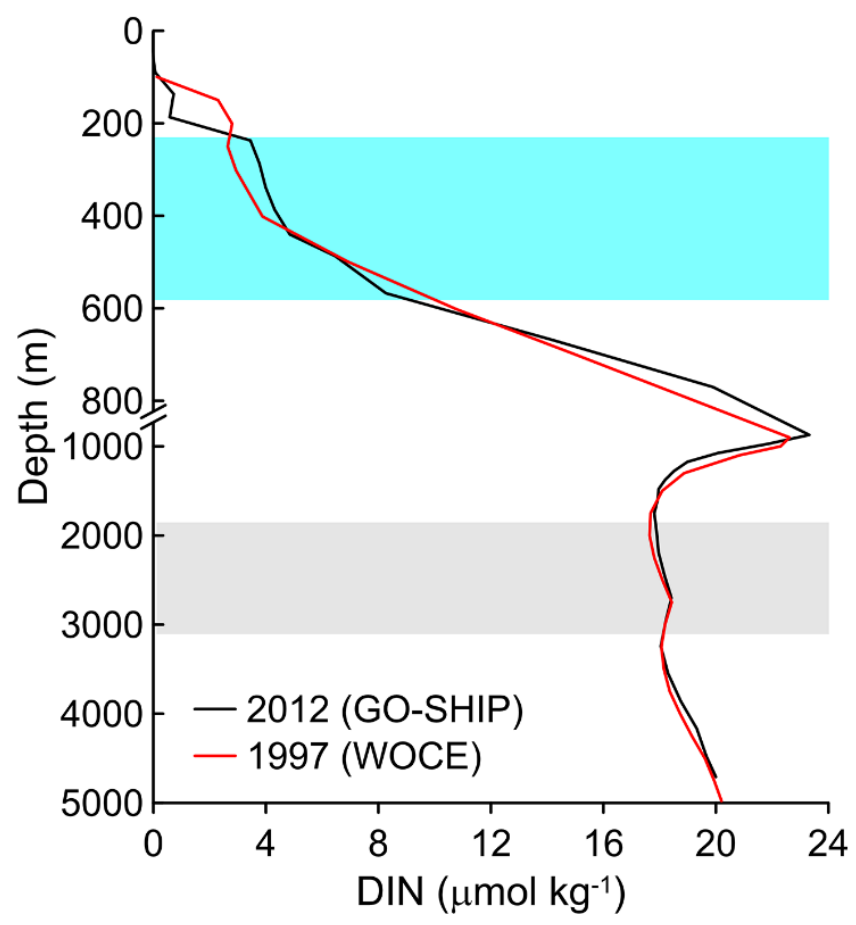

82 Figure S1. (a) Flow chart of the procedure used to adjust the original data from the

83 GLODAPv2 product and CLIVAR database. (b) Example profile of DIN illustrating the

84 adjustment methods. The main adjustments were derived from an examination of the systematic offsets that are shown in Table S2. 

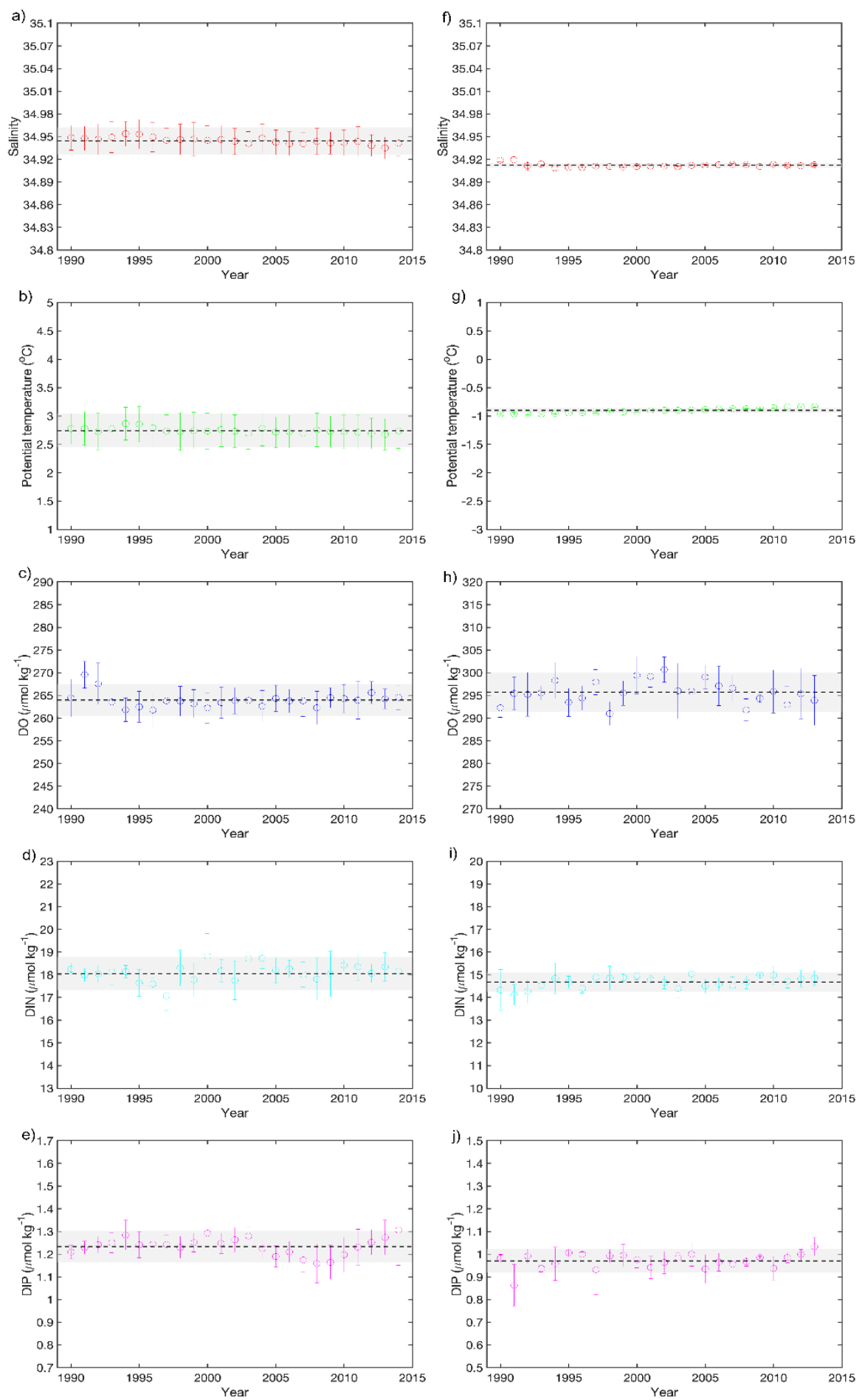

87 Figure S2. Temporal variations in salinity, potential temperature, and concentrations of 88 dissolved oxygen (DO), DIN and DIP for the deep waters at the Bermuda Atlantic Time89 series Study (BATS, 31. $7^{\circ} \mathrm{N}, 64.2^{\circ} \mathrm{W}$ ) site from 1990-2015 (a-e, 2000-3500 m) and a time90 series site $\left(68.0^{\circ} \mathrm{N}, 12.7^{\circ} \mathrm{W}\right)$ from $1990-2013(\mathrm{f}-\mathrm{j}, 1500-1800 \mathrm{~m})$ in the northern Iceland Sea. 91 Data from BATS are derived from http://bats.bios.edu/bats-data/, while data from the Iceland 92 Sea are from the Ocean Carbon Data System, NOAA

93 (https://www.nodc.noaa.gov/ocads/oceans/Moorings/Iceland_Sea.html). 

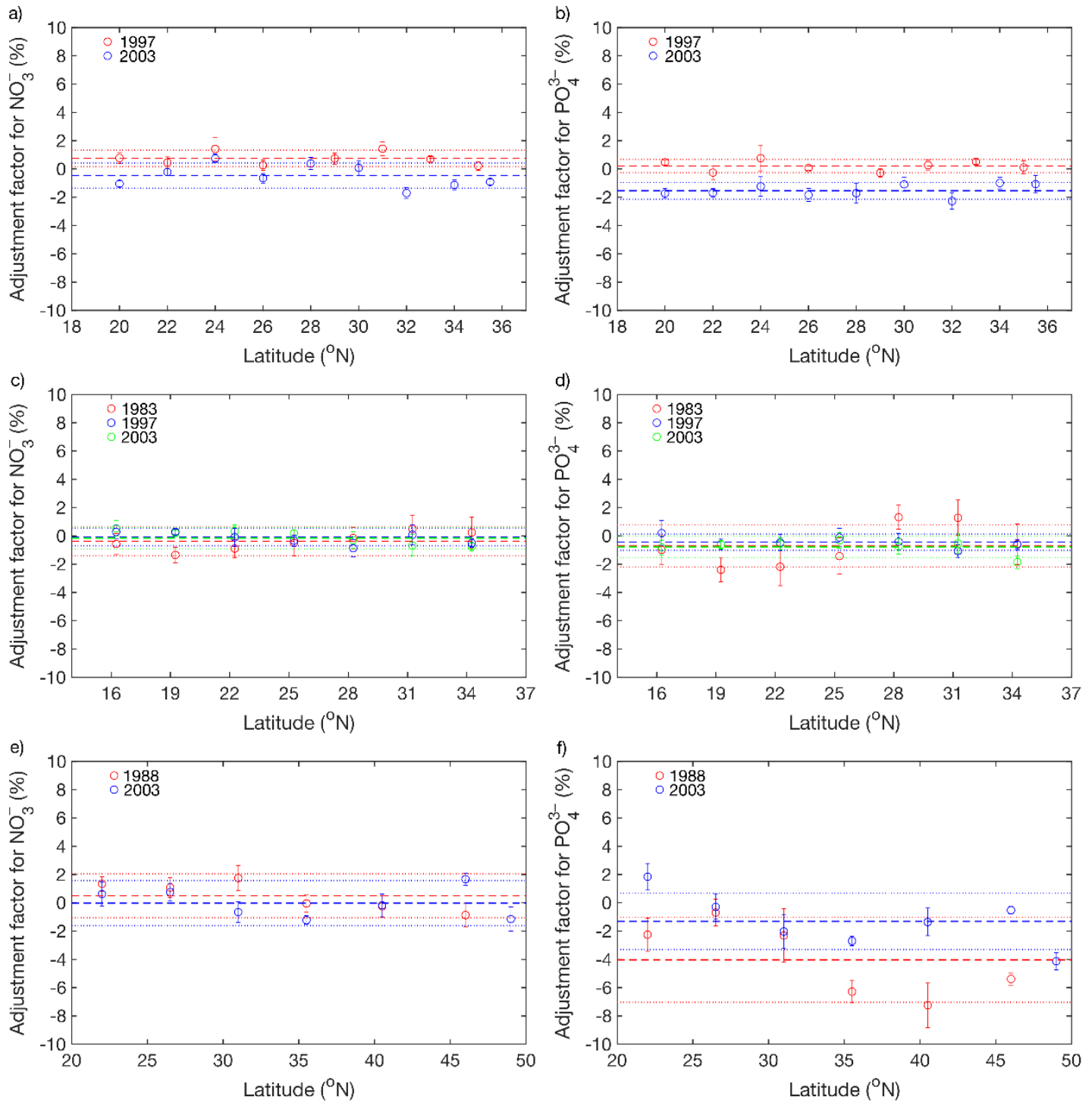

95 Figure S3. Adjustment factors of $\mathrm{NO}_{3}{ }^{-}$and $\mathrm{PO}_{4}{ }^{3-}$ for the major cruises along A22 (a and b),

96 A20 (c and d) and A16N (e and f) by $3^{\circ}-5^{\circ}$ latitude. Data from the latest GO-SHIP cruise

97 along each transect were used as references. The adjustment factors were obtained by comparing the deep-water parameters of different cruises with the reference data. The

99 relatively high adjustment factors obtained for $\mathrm{A} 16 \mathrm{~N}$ are a result of the use of raw data rather

100 than data from the GLODAPv2 product, because the latest cruise along A16N in 2013 is not

101 included in the GLODAPv2 product. 

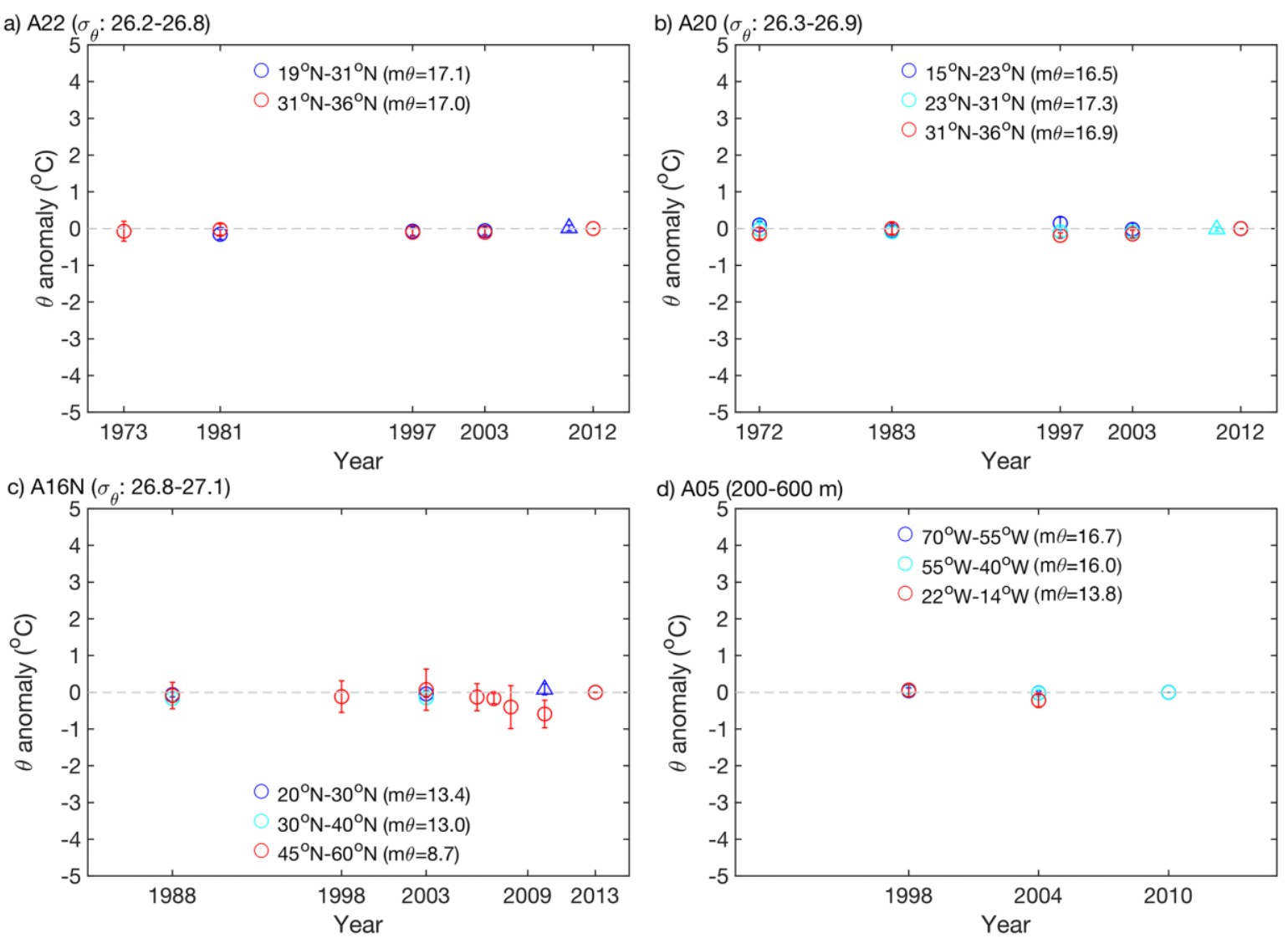

102

Figure S4. Temporal trends of potential temperature $(\theta)$ anomalies (dots) for the

104 corresponding latitude or longitude intervals for the subsurface potential density intervals $\sigma_{\theta}$

105 along the four transects (a) A22, (b) A20, (c) A16N (note that $\sigma_{\theta}=27.2-27.6$ for the latitude

106 interval of $45^{\circ} \mathrm{N}-60^{\circ} \mathrm{N}$ ), and (d) A05 in the NAtl. The date from A05 obtained in 2010 at

107 three crossover sites are also shown in a-c (triangles). $\theta$ anomalies indicate $\theta$ values minus the

108 mean $\theta$ value in the GO-SHIP dataset ( $\mathrm{m} \theta$, values shown in parentheses). The selected

109 density intervals are typically located at a water depth of 200-600 m, which encompasses the

$110 \mathrm{DIN}_{\mathrm{xs}}$ maximum. The selected $\sigma_{\theta}$ intervals in the subpolar region along $\mathrm{A} 16 \mathrm{~N}$ and in the

111 eastern basin along A05 were different, as $\sigma_{\theta}$ for $200-600 \mathrm{~m}$ depth becomes larger in the

112 high-latitude region or eastern basin. The gray dashed line indicates a $\theta$ anomaly of zero. The

$113 \theta$ of a water mass occupying any given density surface did not change between repeat

114 occupations (Student's t-test and ANOVA with Games-Howell test, $p>0.05$ ) along the four

115 transects in the NAtl, except for a slight decrease in the subpolar region along A16N since the

1162000 s. 

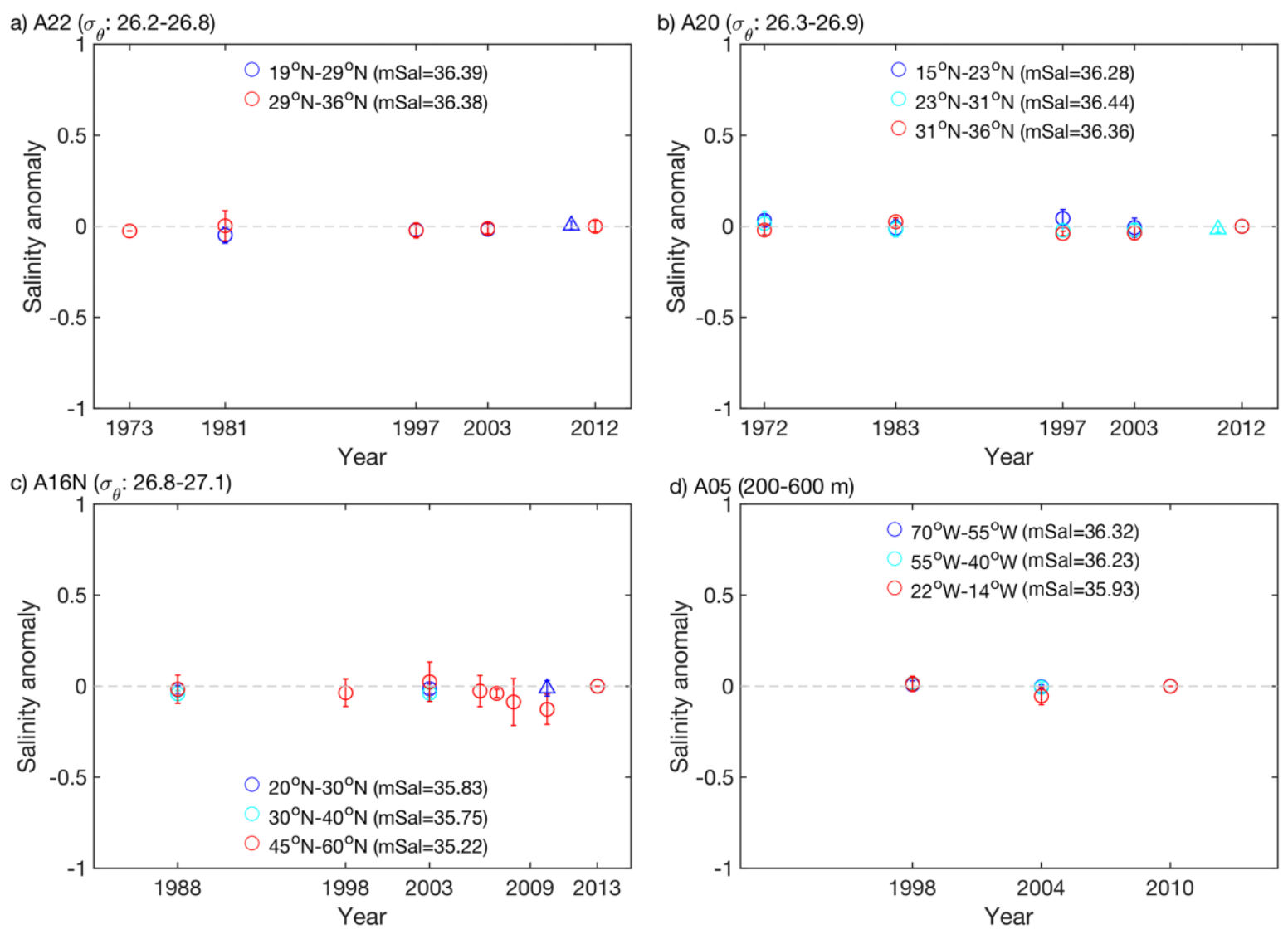

118 Figure S5. The same as in Figure S3 except for salinity anomalies. Salinity anomalies

119 indicate salinity minus the mean value salinity in GO-SHIP dataset (mSal, their values in

120 parentheses). The gray dashed lines indicate salinity anomaly of zero. The salinity of a water

121 mass occupying any given density surface did not change between repeat occupations

122 (Student's t-test and ANOVA with Games-Howell test, $p>0.05$ ) along the four transects in

123 the NAtl, except for a slight decrease in the subpolar region along A16N since the 2000s. 

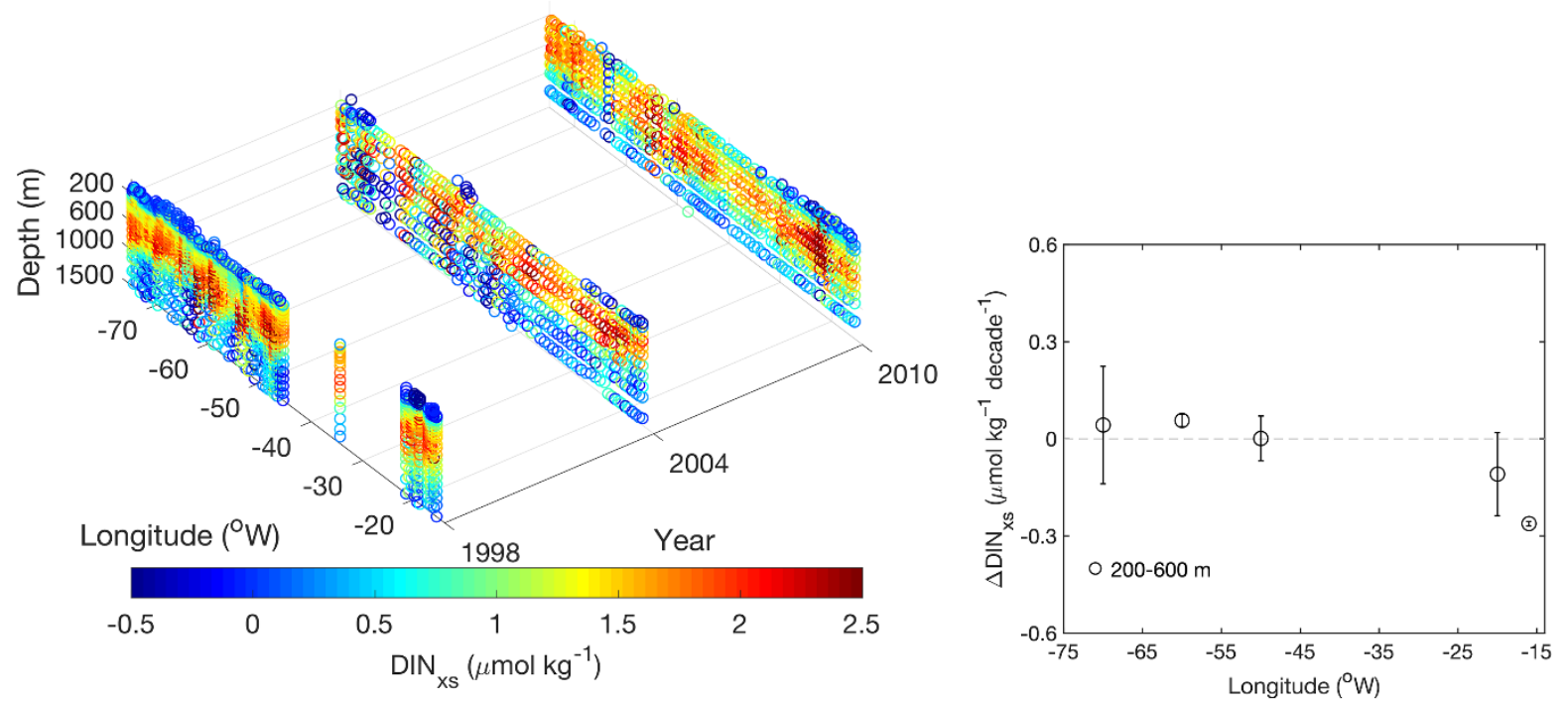

125 Figure S6. The vertical distributions of excess nitrate $\left(\mathrm{DIN}_{\mathrm{xs}}\right)$ in the upper $1500 \mathrm{~m}$ for the

126 difference cruises along the transect A05 in the NAtl. The inset shows the average rates (with

$12795 \%$ confidence limits) of change in $\operatorname{DIN}_{\mathrm{xs}}\left(\Delta \mathrm{DIN} \mathrm{Ns}_{\mathrm{xs}}\right)$ at $200-600 \mathrm{~m}$ averaged for each $6^{\circ}-10^{\circ}$

128 longitude interval between GO-SHIP and WOCE time periods. 


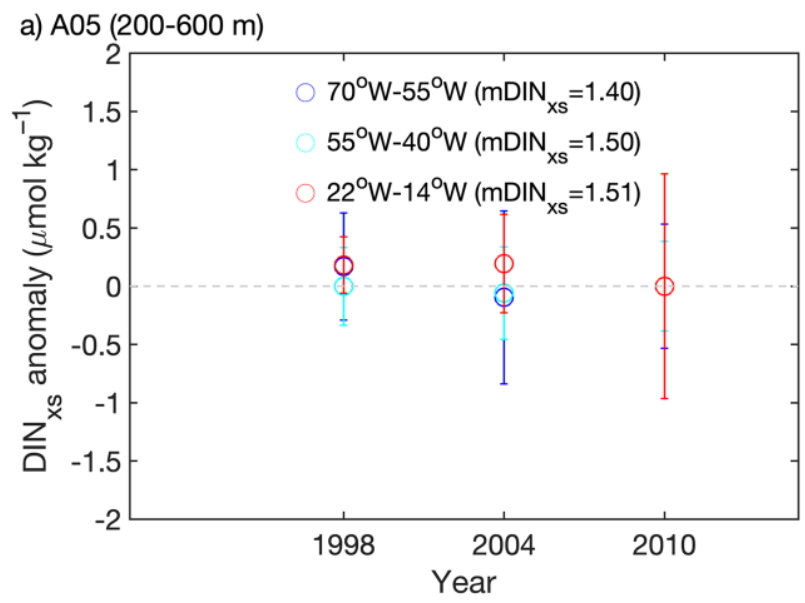

b) $\mathrm{A} 05(200-600 \mathrm{~m})$
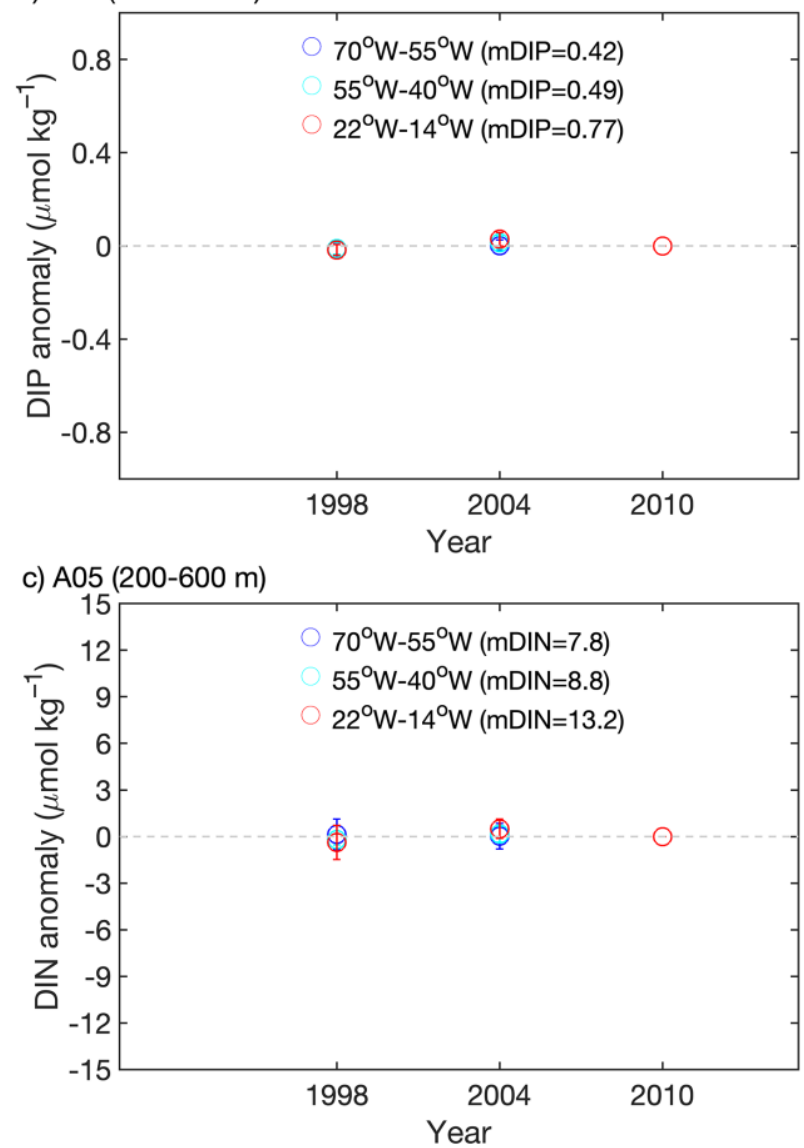

130 Figure S7. Temporal trends of $\operatorname{DIN}_{\mathrm{xs}}$ (a), DIP (b) and DIN (c) anomalies for the

131 corresponding longitude intervals for the subsurface potential density intervals $\sigma_{\theta}$ along A05

132 (see Fig. S2 caption) in the NAtl. DIN ${ }_{\mathrm{xs}}$, DIP and DIN anomalies indicate DIN $\mathrm{xs}_{\mathrm{xs}}$ DIP and

133 DIN concentrations minus the mean DIN ${ }_{\mathrm{xs}}$, DIP and DIN in GO-SHIP dataset $\left(\mathrm{mDIN}_{\mathrm{xs}}\right.$,

$134 \mathrm{mDIP}$ and $\mathrm{mDIN}$, their values in parentheses), respectively. The $\mathrm{DIN}_{\mathrm{xs}}$, DIP and DIN values

135 were corrected by the changes in AOU (see text). The gray dashed lines in (a) and (b)

136 indicate the DIN $\mathrm{xs}_{\mathrm{xs}}$, DIP and DIN anomalies of zero. 


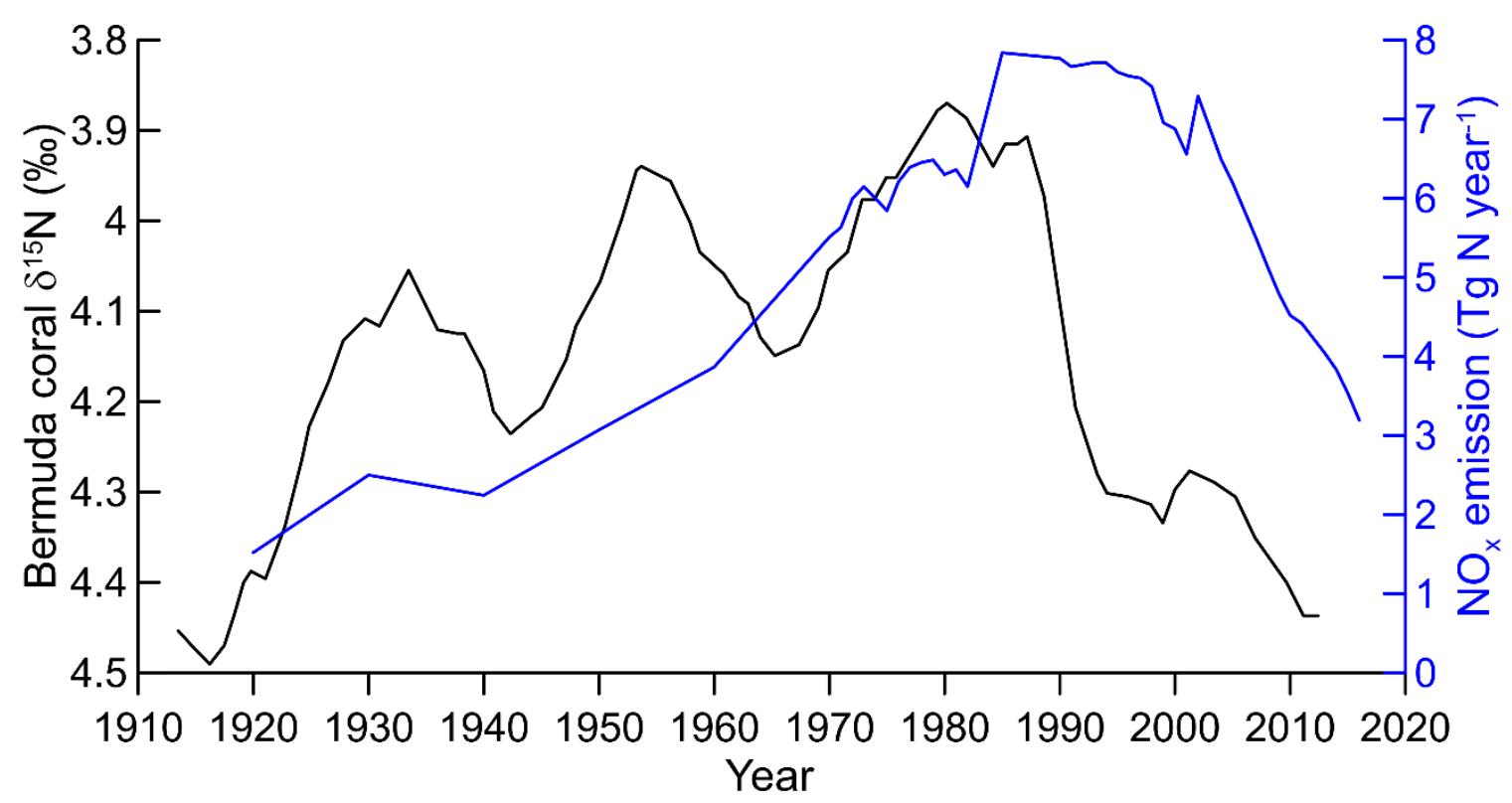

137

\section{Year}

138 Figure S8. Temporal variations of Bermuda coral $\delta^{15} \mathrm{~N}$ (black; Wang et al., 2018) and $\mathrm{NO}_{\mathrm{x}}$ 139 emissions from the USA (blue; EPA, 2000). 


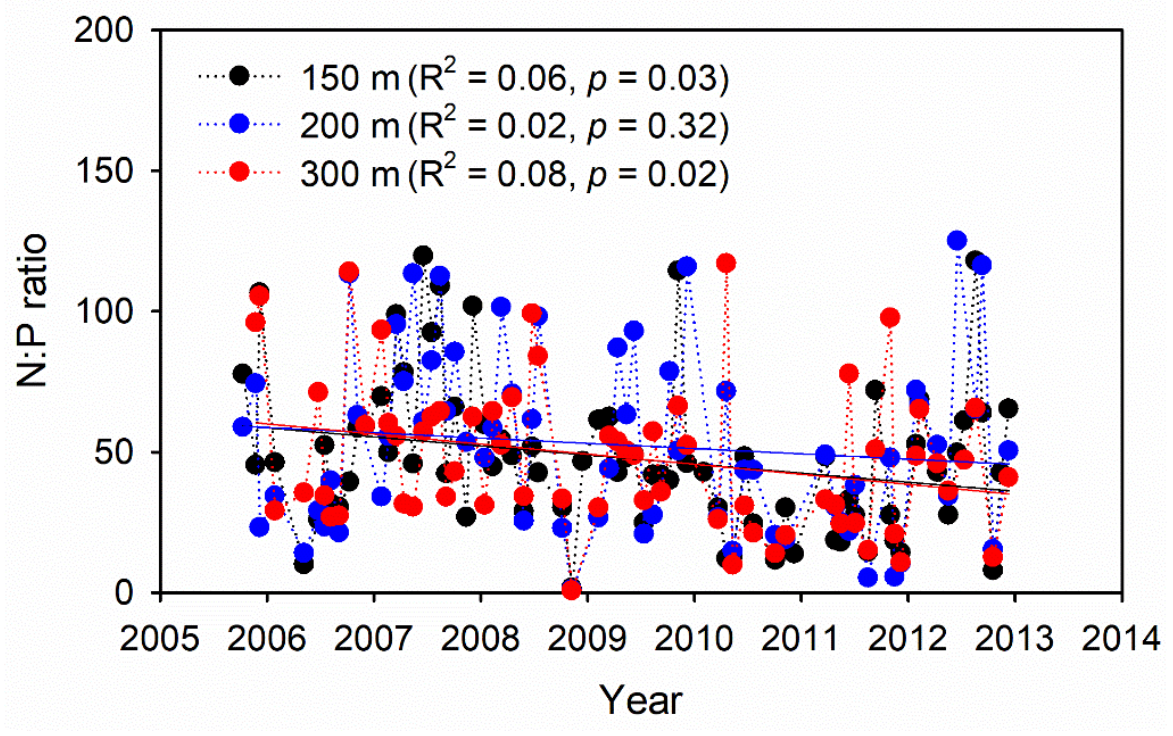

140

141 Figure S9. Temporal variations in the N:P ratios in sinking particles collected between 150

142 and $300 \mathrm{~m}$ at the BATS site. 
143

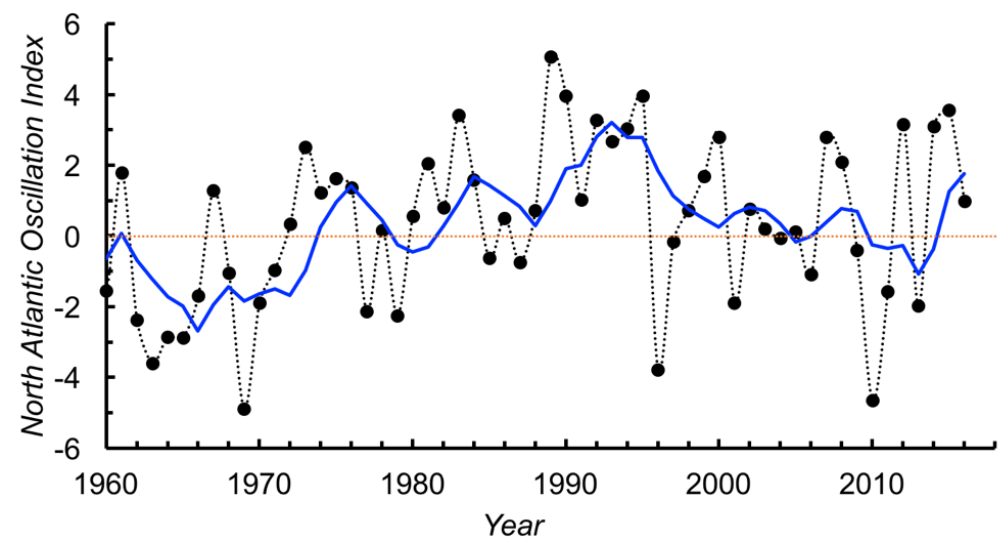

144

145 Figure S10. Temporal variation of the winter North Atlantic Oscillation index (solid dots).

146 The blue curve shows the trend of 5-year moving average. Data are derived from the Climate

147 and Global Dynamics division at National Centre for Atmospheric Research

148 (http://www.cgd.ucar.edu/cas/catalog/climind/). 


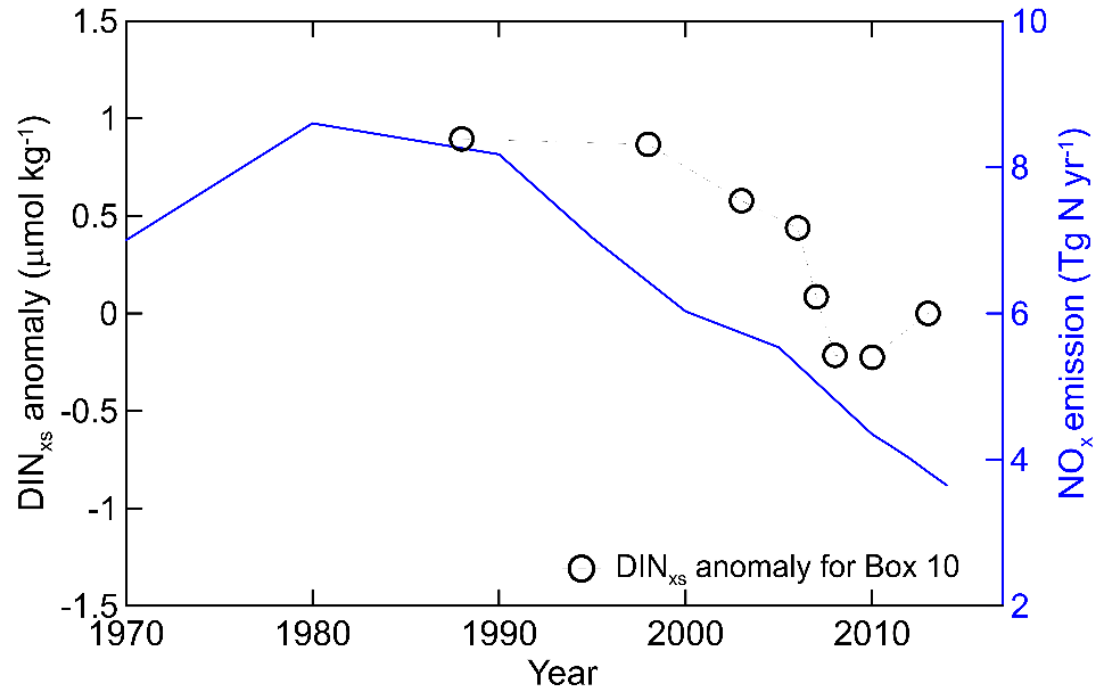

150 Figure S11. Temporal variations in $\mathrm{DIN}_{\mathrm{xs}}$ anomaly in the subpolar region of the eastern

151 North Atlantic where DIN $_{x s}$ decreased significantly (box 10 in Figure 5a). The history of $\mathrm{NO}_{\mathrm{x}}$

152 emissions from Europe (blue curve) is also shown (Adams et al., 2012). 

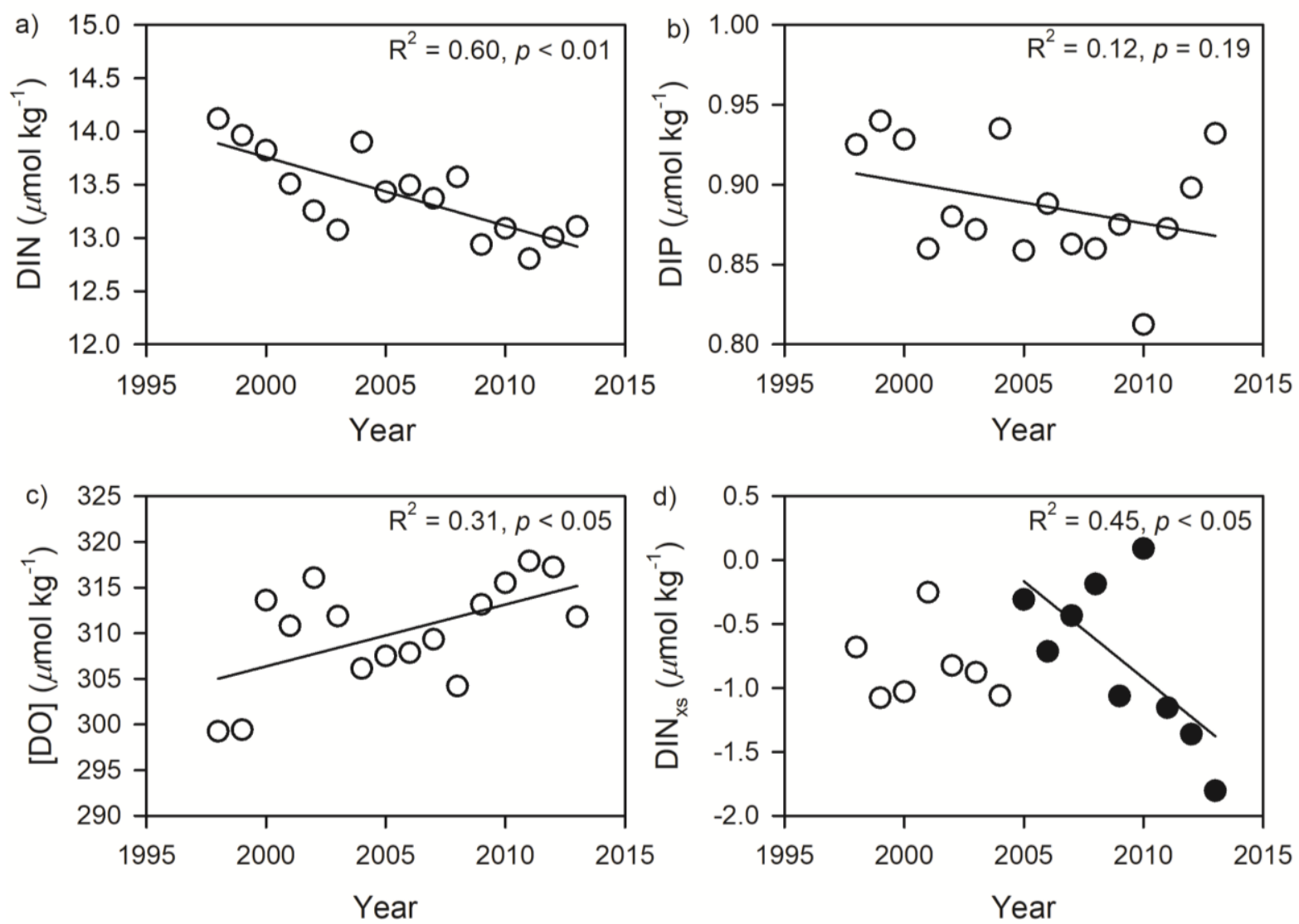

Year

154 Figure S12. Temporal variations of annual average concentrations of (a) DIN, (b) DIP, (c)

155 dissolved oxygen (DO) and (d) DIN $\mathrm{xs}$ in the subsurface waters (300-500 m, potential density $156 \sigma_{\theta}$ of $\left.\sim 28.0\right)$ at a time series site $\left(68.0^{\circ} \mathrm{N}, 12.7^{\circ} \mathrm{W}\right)$ from $1998-2013$ in the northern Iceland

157 Sea. Note that the linear regression in d) only include the data since the decreasing trend is

158 significant after 2005. Data are derived from the Ocean Carbon Data System, NOAA

159 (https://www.nodc.noaa.gov/ocads/oceans/Moorings/Iceland_Sea.html). 
160

161

162

163

164

165

166

167

168

169

170

171

172

173

174

175

176

177

178

179

180

181

182

183

184

185

186

187

188

189

190

191

192

193

\section{References}

Adams, M., Aardenne, J. V., Kampel, E., Tista, M., and Zuber A.: European Union emission inventory report 1990-2010 under the UNECE Convention on Long-range Transboundary Air Pollution (LRTAP), Eur. Environ. Agency, Copenhagen, http://doi.org/10.2800/5219, 2012.

Anderson, L. A., and Sarmiento, J. L.: Redfield ratios of remineralization determined by nutrient data analysis, Global Biogeochem. Cycles, 8, 65-80, http://doi.org/10.1029/93GB03318, 1994.

Broecker, W. S., and Takahashi, T.: Hydrography of the central Atlantic-III. The North Atlantic deep-water complex, Deep Sea Res. Part A, 27, 591-613, http://doi.org/10.1016/0198-0149(80)90076-X, 1980.

EPA: National Air Pollutant Emission Trends, 1900-1998, Office of Air Quality Planning and Standards, Research Triangle Park, 2000.

Gebbie, G., and Huybers, P.: The mean age of ocean waters inferred from radiocarbon observations: Sensitivity to surface sources and accounting for mixing histories, J. Phys. Oceanogr., 42, 291-305, http://doi.org/10.1175/jpo-d-11-043.1, 2012.

Key, R. M., Olsen, A., van Heuven, S., Lauvset, S. K., Velo, A., Lin, X., Schirnick, C., Kozyr, A., Tanhua, T., Hoppema, M., Jutterström, S., Steinfeldt, R., Jeansson, E., Ishii, M., Perez, F. F., and Suzuki, T.: Global Ocean Data Analysis Project, Version 2 (GLODAPv2), (ORNL/CDIAC-162, ND-P093), Carbon Dioxide Information Analysis Center, Oak Ridge National Laboratory, US Department of Energy, 2015.

Olsen, A., Key, R. M., van Heuven, S., Lauvset, S. K., Velo, A., Lin, X., Schirnick, C., Kozyr, A., Tanhua, T., Hoppema, M., Jutterström, S., Steinfeldt, R., Jeansson, E., Ishii, M., Pérez, F. F., and Suzuki, T.: The Global Ocean Data Analysis Project version 2 (GLODAPv2) - an internally consistent data product for the world ocean, Earth Syst. Sci. Data, 8, 297-323, http://doi.org/10.5194/essd-8-297-2016, 2016.

Talley, L. D., Feely, R. A., Sloyan, B. M., Wanninkhof, R., Baringer, M. O., Bullister, J. L., Carlson, C. A., Doney, S. C., Fine, R. A., Firing, E., Gruber, N., Hansell, D. A., Ishii, M., Johnson, G. C., Katsumata, K., Key, R. M., Kramp, M., Langdon, C., Macdonald, A. M., Mathis, J. T., McDonagh, E. L., Mecking, S., Millero, F. J., Mordy, C. W., Nakano, T., Sabine, C. L., Smethie, W. M., Swift, J. H., Tanhua, T., Thurnherr, A. M., Warner, M. J., and Zhang, J.-Z.: Changes in ocean heat, carbon content, and ventilation: A review of the first decade of GO-SHIP global repeat hydrograpy, Annu. Rev. Mar. Sci., 8, 185-215, http://doi.org/10.1146/annurev-marine-052915-100829, 2016. 
194 Wang, X. T., Cohen, A. L., Luu, V., Ren, H., Su, Z., Haug, G. H., and Sigman, D. M.:

195 Natural forcing of the North Atlantic nitrogen cycle in the Anthropocene, Proc. Natl.

196 Acad. Sci., 115, 10606-10611, http://doi.org/10.1073/pnas.1801049115, 2018.

197 Woosley, R. J., Millero, F. J., and Wanninkhof, R.: Rapid anthropogenic changes in $\mathrm{CO}_{2}$ and

198 pH in the Atlantic Ocean: 2003-2014, Global Biogeochem. Cycles, 30, 70-90,

199 http://doi.org/10.1002/2015GB005248, 2016.

200 Zhang, J.-Z., Mordy, C. W., Gordon, L. I., Ross, A., and Garcia, H. E..: Temporal trends in 201 deep ocean Redfield ratios, Science, 289, 1839-1839,

202 http://doi.org/10.1126/science.289.5486.1839a, 2000. 